\title{
Key Issues of Integrative Technology Assessment
}

\author{
Andreas Metzner-Szigeth
}

\section{Introduction}

This paper has been written with the intention to present some conceptual and programmatic considerations. The length of its complete title is therefore nothing less than an expression of the idea to pay attention to far-reaching and broad civilizational and paradigmatic connections instead of focussing on a single area of professional specialization.

In this way - and according to KISS, a well-known principle of great design that says "Keep It Simple and Straightforward" - four clusters of contents will be introduced and treated subsequently:

(1) "Progress", because its shaping is indeed the central subject of governance of science and technology in general and of technology assessment (TA) in particular!

(2) "Vulnerability", because that is the very challenge of our times!

(3) "Sustainable Development", because that really answers the question of how to gain the future!

(4) "Governance of Science and Technology", because evidently there is some discrepancy between a growing demand for a good governance of these issues and a lack of satisfying strategies and concepts of how to do that! Therefore - and because of the fact that technology assessment is of crucial importance for any ambitious governance approach I would like to introduce a framework concept that I call "Integrative Technology Assessment" (ITA).

Moreover, and in order to develop my argument in a clear and understandable way, there will be composed four general theses on the line of the four points, one of each for "progress", "vulnerability" and "sustainable development" plus one for the concluding general thesis.

\section{Progress}

\subsection{Progress and Enlightenment}

European modernization has been - and in fact is - determined by the thought of "enlightenment" but also by the idea of "progress". Whereas one of them intents to foster the human faculties for reasoning in the sense of independence and self-responsibility, the other one tries to examine and tame the forces of nature with the instruments and media of science and to develop and utilize them in form of technology. The promises of this civilizational initiative are "freedom", "wealth" and "security".

\subsection{Progress and (In-)Security}

"No one should hinder progress!" So a popular speech reads. In this an one-dimensional apologetic comprehension of progress comes to expression, which indeed conflicts most vehemently with the - in the same way one-dimensional - apocalyptic understanding of progress, which comprehends progress (under changed pre-signs) as an unstoppable allengulfing "Juggernaut". But the deterministic, unilinear model of progress breaks much more systematically with an opinion that understands progress not essentialistically but processoriented as increase of design or shaping possibilities and development options.

In the sense of the last opinion, progress was and is and will be practice, a process powered by human actors and formed by them in mode and manner (cf., among others, Bijker et al.

1 See, among others, Berting 2006, pp. 39ff., for the complex interplay of cultural reasons of this transformation that are especially linked with the pair of secularization and rationalization. 
1987; MacKenzie/Wajcman 1985). Therefore, and regardless of its past, present or future, progress is a socially shapeable process, which characterizes itself in so far, as it does not just reduce contingencies - thereby determining the direction and the further possibilities of development cumulatively - but multiplies contingencies, while opening up new options permanently.

Progress - a mixture of "chances" and "risks" - must therefore be ambivalent by its very nature: progress is creating securities, in so far as it contributes to the solution of existing societal problems, thus performing like "keeping-things-in-order" and stabilizing better living conditions; and progress is acting as an "insecurity generator", while multiplying options that are to be coped with as decisions under uncertainty, which are questioning the "status quo" permanently.

\subsection{Progress, Reflexivity and Domination}

In the circles of scientific-technological progress of course questions and doubts emerge: Do the strengths of the sciences suffice in order to cope with or compensate for the ensuing consequences and shaping problems of modernization? Or are the problem-generating potentials of science and technology greater than their problem-solving capacities? Does it therefore go ahead? Or are we caught in a spiral? ${ }^{2}$

Trying to answer these questions Ulrich Beck, in his book about the "Risk Society", has introduced for that the terms of the simple and reflexive scientification ${ }^{3}$ : The stage of the "simple scientification" is characterized by the application of science to the "original" ("virginal") world of nature, human being and society. On the other hand, in the "reflexive stage", the sciences are dealing with a modified world, already altered by science and technology - and while doing so, they are confronted with the products, shortcomings, consequences and shifted problems of their own "success".

With the increasing necessity for overcoming or compensating the aftereffects, problems and risks that emerge within the relationship of human society and ecological environment, the characteristic pattern of scientific knowledge changes: Formerly, science was thought of as a producer of the instruments and remedies for an increasing "control of nature", (that was supposed to be) accompanied by a (more and more) rationally "planned development of society". Nowadays, that science has to dedicate itself to the problem of the successful appropriation of nature (as well as the successful ignition of society's modernization) - it has altered into a "reflexive science". This one is confronted more and more - so my subsequent thesis reads - with the task of "mastering the domination of nature" that comes to expression, for instance, in the ever-growing demand for the control of intervention consequences and not intended side effects.

The evolution of science and technology has become contradictory in itself, because it is according to Beck - simultaneously a complementary cause, a definitional remedy and a source of solution for problems. Inter- and trans-disciplinary approaches, as they have been practiced for a long time in systems analysis and technology assessment, are therefore becoming year by year more necessary in order to shape the scientific-technological progress. But their "business" becomes also ever more difficult.

\subsection{Progress and Industrial Innovation Cycles}

In order to achieve its contribution, the social scientific science-, technology-, environmentand risk-research is being required, not only to reflect the cultural (communicative, symbolic)

2 In a spiral of ever more new problems to solve, originating from earlier attempts to do exactly that, namely to solve problems.

3 Cf. Beck 1992 and further Beck 1999; for similar ideas and discussions cf. also Giddens 1990; Beck et al. 1994; Lash et al. 1996. 
reality of developed industrial societies, but to do that in the context and in the inner connection with their material (substantial, infrastructural) reality. ${ }^{4}$

In which way that could be done, will be demonstrated now in the context of "industrial innovation cycles" . The main ideas of the illustration presented in Figure 1 are: Each basisinnovation or key technology ${ }^{6}$ (e.g. steam engine) releases a series of process innovations (in the example power and work machines) and finally condenses in a techno-industrial innovation cycle. The two "classical" innovation cycles I and II are indicated here as that of "coal \& steel" and of "electrical engineering \& synthetical chemistry". They are followed by two "neo-classical" cycles: III, which is yet in plain development, and IV, which is partly beginning to be indicated by fore-signs. Their direction of movement is: from "electronics" over the "information and communication technologies (ICT)" to the further basis innovations of the "bio and gene technologies (BGT)" and the "microsystem and nano technologies (MNT)".

4 Cf. Metzner 2002, where this approach has been elaborated and proved to be worthwhile.

5 I am using this term that is inspired by the economical ideas of Nikolai Kondratieff and the works of Alvin Toffler because of its structural instructiveness in order to analyze patterns of development; cf. also Barnett 1998; Freeman/Louçã 2001.

6 The terms "basis innovation" and "key technology" are used more or less synonymously here because of some fundamental functional similarities, despite of other also important differences. Cf. in that context Godin 2006, who presents the strength and weaknesses of the linear model of innovation in the context of his analysis of its scientific-historical development. Other accentuations are expressed with "generic technologies", that promise new methods and innovative solutions, and "general purpose technologies" (GPT), which dominate whole areas of technical progress and growth, such as the steam engine, the electric motor, and semiconductors because of their pervasiveness and inherent potential for improvements (cf. Bresnahana/Trajtenberg 1995). 
Figure 1: $\quad$ Industrial Innovation Cycles and their Consequences

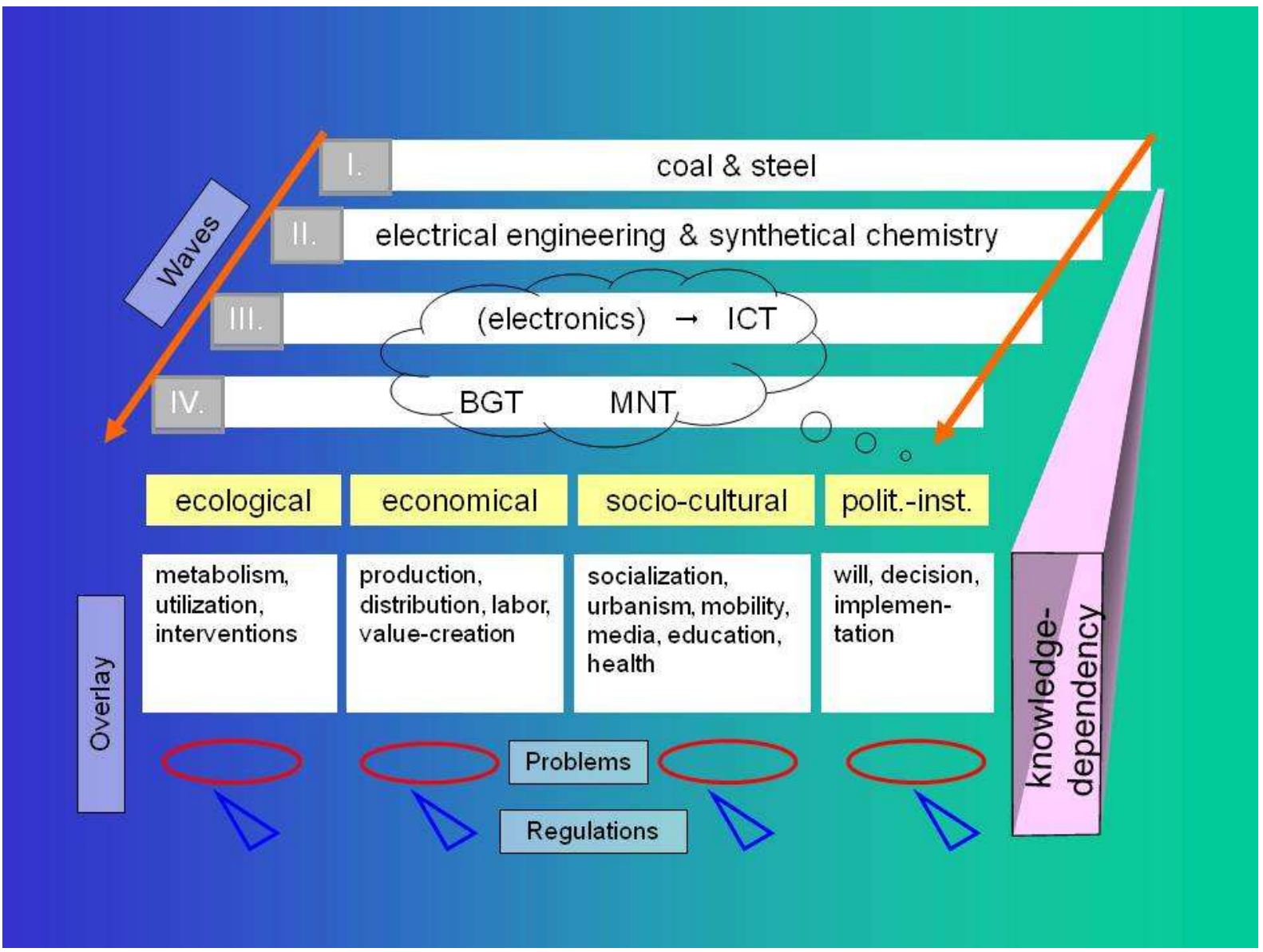

Author's archive

Moreover, and without yet being able to clear its systematic position in the context of the industrial innovation cycles just introduced, there is to mention the concept of "converging technologies" (indicated by the cloud in Figure 1) that proposes some dynamic convergence between information technology (ICT), biotechnology (BGT), nanotechnology (MNT) and further very dynamic areas like brain research and psychopharmacology which are not only occasionally linked with visions of "human enhancement" (cf. Roco/Bainbridge 2004). The concept of converging technologies - also known as NBIC, an acronym for nanotechnology, biotechnology, information technology and cognitive science - has up to now been more programmatic than descriptive, but its relevance as a vision that already is on its way to guide or direct some branches of further techno-scientific development is of utmost importance (particularly when transcending a viewpoint interested in competitive advantages only) (cf., among others, ETAG 2006; Grunwald 2007; Nordmann 2004).

Each of this innovation-cycles provokes wide-range "transformations", that are shaping the "Gestalt", that is the configuration and the dynamics of the industrial (and meanwhile post-industrial) society. The emerging consequences of these transformations are materializing subsequently and are together forming an overlay-zone, that is successively moving forward in time. This happens:

7 Meant is something that is comparable in scope and range with that "great transformation" described by Karl Polyani; cf. Polyani 1944 and the review of Mayhew 2000; cf. also the next reference about "socio-ecological transformations". 
(1) in the profile of the metabolism with nature, including the quality and quantity of flows of energy and materials (cf. Haberl et al. 2004; Schiller 2009; Suh 2005), the form and degree of the utilization and charge of environmental goods and services, and the extension and intensity of manipulative interventions in the physical-organic world;

(2) with reference to the structure of the economic basis that is related to the configuration of productive forces, the allocation of resources, the distribution of wealth, the patterns of consumption, the organization of labor, or finally the form and length of product-lifecycles and value-creation chains;

(3) with regard to the socio-cultural patterns of society-building, of co-existence and individuation (that is, of living together in families and communities that are altering in scope, function and cultural meaning), as well as referring to the patterns of urbanity, mobility, informing and communicating with media or organizing education and public health;

(4) in relation to the organizational forms of the public will-building and the political decision-making procedures that become mediated especially by those technologies and media that re-organize mobility and communication (cf. Banse/Metzner-Szigeth 2011; Castells 1996), and that includes also the administrative preparation and implementation of programs and actions.

These transformations - that already have been presented here separated according to the four dimensions of sustainable development - are obviously influencing each other. ${ }^{8}$ They are not developing separated from one another, and are (besides their analytical distinction) predetermined for being deciphered by some "systemic" approach (cf. Hjorth/Bagheri 2006; Metzner 1998; Spangenberg et al. 2002) because of their complex inter-dependencies. With respect to ecology - for example - the "classic" industrial society innovation cycles I and II that is being connected with the key sectors of coal and steel industry as well as with the branches of electrical industry, automobile production and synthetic chemistry, corresponds with "problem-clusters" (pointed out in the Figure 1 by red circles), that are characterized, on the one hand, by the charge of the environmental media (water, earth and air) with mass pollutants (as, for instance, phosphates, heavy metals and carbon dioxide) and, on the other hand, by the scarcity and imminent shortage of environmental goods or natural resources (above all those not renewable like fossil energy sources).

Mediated by these problem clusters are corresponding specific "regulation-approaches" (pointed out in the Figure 1 by blue triangles) with the innovation cycles and the transformations that have been released by them. In the example of the environment-related consequences of the and cycles I and II these are the strategies of the technical and the administrative environmental "protection" as well as the "recycling" of valuable resources.

The following innovation cycles III and IV are leading to transformations that are not only interacting with one another, but also with the states that have been built from antecedent that is foregoing transformations. An example for such a transformation - here with regard to the economical dimension - is the reconfiguration of production factors, value-creation chains and economical sectors by the information and communication technologies (cf. Castells 1996; Hodgson 2000; Stehr 1994).

Moreover, Figure 1 indicates that in the transition to the both "neoclassic" innovation cycles, there will be created not only altered problem clusters, but also an overload of the up to then developed regulation approaches. Examples for that are the appropriation and utilization rights of "genetic resources" (cf. Cassier 2002), that are conflicted intensely, as

8 The term of "socio-ecological transformations" (cf. Becker et al. 2000) gains considerably more analytical power when expanded and differentiated like in the fourfold scheme presented here. 
well as the "digital rights" (cf. David 2001), that are laying in midst of no less vehement struggles.

\subsection{First General Thesis and its Explication}

The first general thesis results from all considerations presented so far. It says: The more the scientific-technological progress advances, the more dependent on knowledge and science becomes the task of its constructive shaping!

In other words, more politically spoken, the same finding could be expressed as follows: The governance of science and technology becomes the more dependent on the contribution of scientific and professional experts, the more science and technology are moving forward. The governance of science and technology becomes therefore less and lesser a purely political issue that could be dealt with successfully by politicians alone. Either the (governing) politicians and their (not only executing) administrators as well as the (governed) citizens need to be well-informed in order to provide for good decisions by transparent and effective decision-making procedures. And, in the case of governance of science and technology, the state of being well-informed is not reachable without assistance (knowledge, competencies and assessments) of those scientific and professional experts whose working results are composing the subject at stake.

The essential points of the first thesis can be explained as follows: Together with the ongoing and increasing scientification of the techno-industrial procedures for producing ever more complex products, there grows also the knowledge and science dependency of the possibilities for the identification and regulation of the consequences of their production, application and disposal. An example for that is the general debate of the "pros" and "cons" of modified crops (cf. Rissler/Mellon 1996) and the particular discussion about the "monitoring" of the possible release and diffusion of genetically modified elements of plants (cf., e.g., Barton/Dracup 2000), e.g. of oilseed rape, because of their potential adverse effects especially for biodiversity. Moreover, there is to mention that this monitoring requires the application of molecular-biological diagnosis methods whose reliability is still not very clear because they share the same origin as the disputed newly developed techniques. The same example illustrates that together with the increasing knowledge dependency also the uncertainties of prospective knowledge - that is crucial for informed decision-making - are expanding. ${ }^{9}$ In addition, there is to recognize the boosting of complexity due to the overlapping consequences of the transformations released by the successive innovation cycles. The regulation-knowledge of the various consequences must also be produced faster in order to keep up with the innovation speed.

Up to now - in Chapter 2 - we have examined the shaping problem of the scientifictechnological progress departing from the forces and consequences, which have been set in motion by progress itself. We are turning now into another perspective, in order to examine in Chapter 3, "Vulnerability", the shaping problem the other way round, departing from the "weakness" of the modern society and the need of scientific-technological creativity.

\section{Vulnerability}

\subsection{Vulnerability: Levels, Components and Definition}

"Vulnerability" has an external and an internal component. In general are - on the micro-level - the individual human being, or the single community (or livelihood) in which he or she lives, and - on the meso-level - the single city or region or the particular differentiated functional system, or finally - on the macro-level - complete societies exposed to existential

9 Cf. Wehling 2006; Metzner-Szigeth 2009; especially with regard to uncertainties of climate prognosis and global environmental change scenarios. 
hazards ("exposure"), and are to some distinct degree able to encounter this "being-exposed" either out of own strength or with assistance from others or third parties ("coping"). ${ }^{10}$

In order to present an example that can illustrate the given argument we could contrast two coinciding cases: ${ }^{11}$ In 2010, Haiti (on January 12) and Chile (on February 27) suffered from major earthquakes, with 7,0 (Haiti) and 8,8 (Chile) points on the Moment Magnitude Scale (MMS). Despite the fact, that the sheer amount of the released potentially destructive energy was considerably greater in the case of Chile, one can observe that the Haiti quake was far more destructive in terms of its outcome (number of killed persons and cumulated damages). An explanation for this finding is that the exposure to the quake was different in both cases due to a different configuration of decisive (physical and societal) factors. Moreover, in the case of Haiti the action capacities decisive for the autonomous coping capabilities of this society were already at ground level (for several other reasons) when the catastrophe occurred. The combination of both was inevitably leading into the following humanitarian disaster and might also be an explanation for the finding, that the attention of the global public to the Haiti case was considerably larger.

Anyway, we should try to understand the nature of vulnerability apart from single cases and isolated events. Following the idea of "glocalization" (cf. Robertson 1995; that combines the two seemingly contradictory trends of globalization and localization in one artificial expression) we can say here that we do have a "hybrid pattern" of local, regional and global vulnerabilities that are intertwined. A governance approach that aims to encounter "global risks" would therefore be misleading if and in so far as it would not recognize the nested character of these vulnerabilities. Neglecting that characteristic in favor of the primary attention to the global scale would force us to remain on the surface instead of analyzing the deeper structure and would therefore finally lead to the (of course not intended) consequence of missing to recognize the particular synergies caused by the dynamic interactions of the components of that nested systems.

\subsection{Vulnerability: Overview on the Configuration of Interdependencies}

Vulnerability is some kind of "fuzzy concept". Due to its association richness as well as to its convincing core idea it is, however, very instructive. ${ }^{12}$ Its great value can be shown best while analyzing the whole complex of hazards and vulnerability in its interconnection with the ensemble of techno-industrial devices, systems and infrastructures (whose dynamic is driven by scientific-technological knowledge and competencies) and with regard to risk and the notions of prevention and resilience that provide for some mental tools that are serving simultaneously as regulative ideas and interventional concepts that we use in our trials to encounter the challenges that are emerging out of this complex (see Figure 2).

${ }^{10}$ With this adapted differentiation I am following the definition of Robert Chambers: "Vulnerability $[\ldots]$ is not the same as poverty. It means not lack or want, but defenselessness, insecurity, and exposure to risk, shocks and stress. [...] Vulnerability here refers to exposure to contingencies and stress, and difficulty in coping with them. Vulnerability has thus two sides: an external side of risks, shocks, and stress to which an individual or household is subject; and an internal side which is defenselessness, meaning a lack of means to cope without damaging loss. Loss can take many forms - becoming or being physically weaker, economically impoverished, socially dependent, humiliated or psychologically harmed" (Chambers 1989, p. 1; cf. also Watts/Bohle 1993).

11 An excellent source of further information that introduces simultaneously in methods of how to organize such a comparison is offered by The Learning Network of the New York Times (cf. http://learning.blogs.nytimes.com/2010/03/02/two-earthquakes-in-two-months-comparing-thequakes-in-haiti-and-chile/).

12 Even the positive meaning of vulnerability as analyzed by Bijker 2006 in the contexts of technological culture and innovation dynamics can show this. 
Figure 2: $\quad$ Vulnerability and its Implications

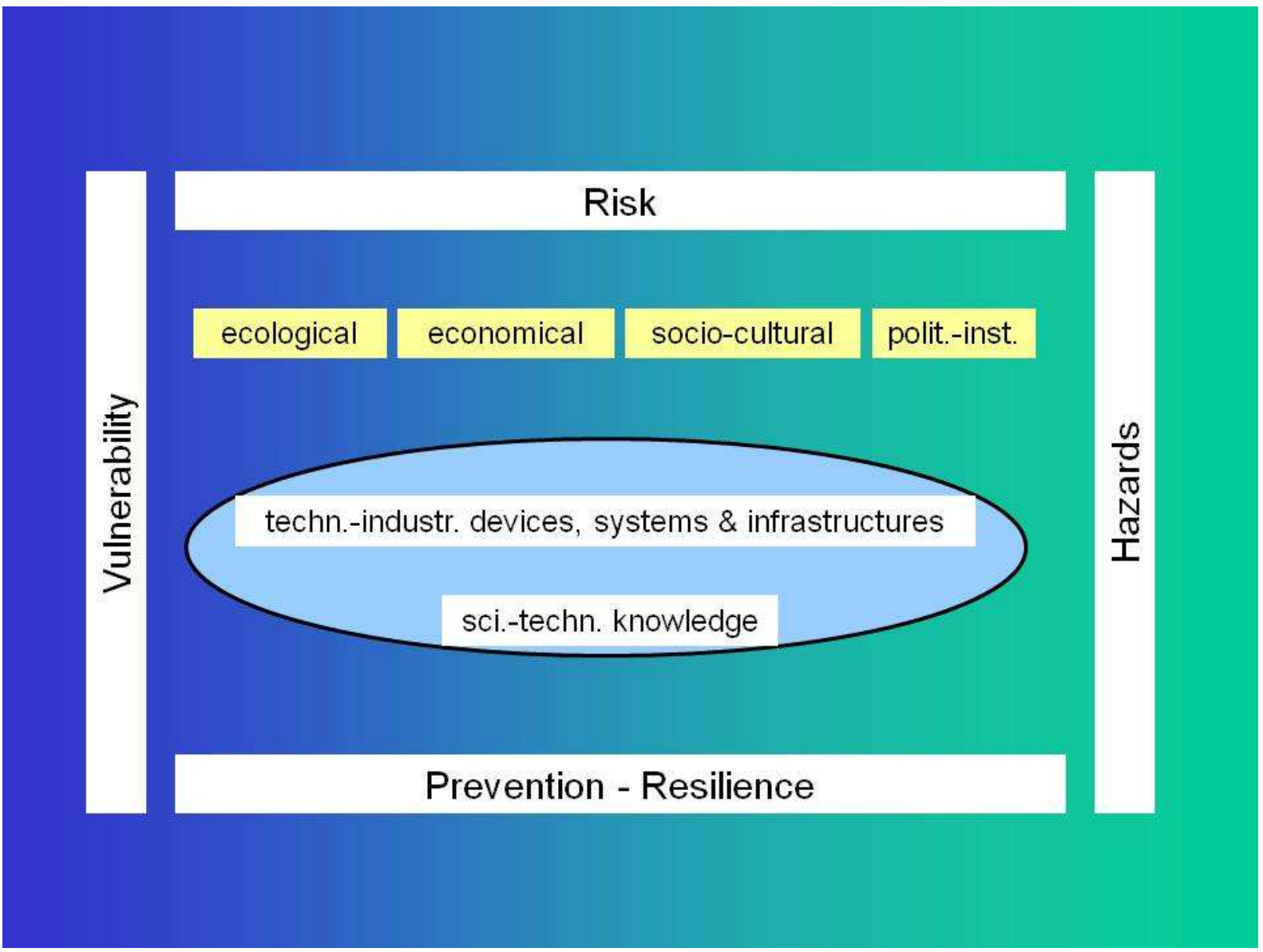

Author's archive

Figure 2 shows on the right a bar with the denomination "hazards". ${ }^{13}$ These are to be classified according to different subsets:

(1) Epidemics, as for instance AIDS, $\mathrm{BSE}^{14}$, bird flu or (the official declared pandemic of) $\mathrm{H} 1 \mathrm{~N} 1$ (that stayed out fortunately);

(2) "Natural"-disasters, including those that have some causal nexus with global environmental and climate changes, and are therefore hardly any more natural phenomena, but also of anthropogenic origin, as e.g. storms, landslips and avalanches, floods, droughts and earthquakes (cf. Abramovitz/Starke 2001);

(3) Techno-industrial accidents, that is essentially man-made incidents like that of the type "Seveso" (1976), "Bophal" (1984), "Chernobyl" (1986), "Exxon Valdez" (1989) or (most recently) the "Deepwater Horizon" (2010), but of course also those of "smaller" range (cf. Pidgeon/O’Leary 2000);

(4) Military struggles or civil wars, in whose consequence, for instance, oil fields are burning or once fertile regions are devastated (like in Iraq or Dafur);

(5) Terrorist attacks and acts of sabotage, above all insofar as they are suitable to provoke massive losses of human lives and/or the break-down of social infrastructures and function systems (like e.g. Internet-communication or the world-wide electronic stockmarket or the trans-regional power supply). Examples for that are the (,9-11“) attack on

${ }^{13}$ Further clarification about the definition and differentiation of the interrelated concepts of hazard, danger, accident and others could be found in Fisher 1994.

14 Bovine Spongiform Encephalitis, better known as "mad cow syndrome". 
the "World Trade Center" or the recent attack on a hydroelectric power plant in the Russian city of Baksansk (in July 2010) but also - less spectacular - the seasonal "computer-viruses" and "software-worms" or the - in the public widely unknown "cyber attack" (cf. Barletta 2008) on Estonia in 2007.

To the left we see a bar with the denomination "Vulnerability". There could be assigned a whole line of factors to it that can be divided at least in two categories:

(1) Factors of general nature, as e.g. the increasing density of interactions, the increasing networking-degree, the growing population, the increasing interdependencies between more and more specialized and differentiated systems, with services and productive units that are necessarily bound to a permanently running stream of transactions between them that leads to a growing sensitivity to interruptions and disruptions, and particularly united with "globalization" - the "de-limitation" of large-scale and space-crossing causeand-effect-chains (cf. Beck 1999a, 1999b; Held 2000; Lubbers/Koorevaar 2000; Young et al. 2006);

(2) Factors of particular nature, that are constituting "weak points" that could destabilize whole systems if they are exposed to "critical events" as e.g.

- related to the ecological environment: the charge or degradation of freshwater ecosystems or mountain landscapes;

- related to the economy: the dependency on single key resources, the rate of sources of income, or the quota of indebtedness;

- related to the socio-cultural dimension: the knowledge and faculties of the people in relation to their access to education and other reservoirs of knowledge (catch word "digital divide");

- related to the political-institutional dimension: the possibilities to participate (actively) in processes of decision-making and to receive the information necessary in order to do so.

In sum: The quantity and quality of governance faculties and management competencies are decisive parts of the entire self-organization capacity that is equal to the degree to which a society is capable to regulate itself (while referring simultaneously to internal alterations and structural shifts as well as to external turbulences and changing environmental conditions) and to perform intentionally caused reforms that change central parameters or the complete pattern of its operational self-processing and systemic reproduction.

In addition, there are factors that make sense with regard to techno-industrial devices, systems and infrastructures, as e.g. the factors of "high complexity" and "dense coupling", marked by the risk researcher Charles Perrow, that are above all problematic, if they are occurring together (cf. Perrow 1984); as well as the - by the complexity-researcher John Casti emphasized - "adaptability" of technical systems towards variable or even turbulent environments and critical events (cf. Casti 1994); the degree of "error-friendliness" or "reliability" of processes; the "robustness" of installations; the "singularity" of structures of the built-environment, as for instance bridges, tunnels, fill dams for purposes of territorycrossing supply; or (in contrast to the decentralized architecture of the highly complex but still robust Internet; cf. Willinger/Doyle 2002) the "centrality" of infrastructural networks (if, for instance, all subway lines are going through one "main station"). ${ }^{15}$

As a rule scientific-technological knowledge is meant to be used for serving "constructive" ends. ${ }^{16}$ We know that this not always succeeds, and that vested interests are trying to

15 Cf. also the "large technical systems"-approach (e.g. Joerges 1996).

${ }^{16}$ Here it may make sense to add a longer reference with regard to the utilization of scientific and technological knowledge for "destructive" purposes also, as for instance, weapons. One argument 
influence science and technology, or simply to misuse them, we also know. Nevertheless, presumably all persons acting in "science, research and development" are dealing with the question of how could it be reached best (... to serve constructive ends) - at least in the context of the particular tasks and disciplinary issues that they are working on as a result of the division of labor in the whole society and within the sciences. The general occupation with the question of how this could be reached best, also with attention to the various goals that are linked with the four dimensions of sustainable development, is, however, the original and proper area of Science/Technology-Governance and TA. ${ }^{17}$

The upper bar with the denomination "risk" does not stand by chance between the vulnerability on the left and the hazards on the right side. This should demonstrate, that the measure of being-exposed-to-hazards, related to the scale of damage on the one hand and the probability of occurrence on the other, is to be seen in correlation with both, either with the (potential) hazards as well as with the (latent) vulnerability.

Something similar is true for the (inter-dependencies of the) bar at the bottom with the denomination "prevention and resilience". ${ }^{18}$ In case of prevention the subject is, to limit damages and to reduce the probability of their occurrence, before the risks are manifesting themselves as events. In case of resilience the subject is in adverse, to provide assistances and to be able to achieve compensations, after the risks in question have realized themselves in events. Whether enough has been done (also with regard to the alternate but interrelated strategies of climate change adaptation, CCA, and disaster risk reduction, DRR) can be judged in both cases only in relation to the potential hazards and the latent vulnerability. ${ }^{19}$

\subsection{Second General Thesis and its Explication}

Now we are coming to the second general thesis. It says: The less it succeeds to shape the scientific-technological progress constructively, the more vulnerable becomes modernity!

against the proximate objection that therefore it might be better not to use that term could be to make a distinction between the legitimate and the illegal production and application of these devices. Another argument is to mention the ambivalence of the term "constructive", especially in connection with another use of that term in engineering (cognitive) and humanities (normative), and to make use of that ambivalence. The verb means for the former ones an activity to build an artefact and for the latter ones an activity to perform in a problem-solving manner. Against the background of the two sides of this distinction grows the chance to argue that the intention of my introduction of the term "constructive" (especially as used in the propositions of the four general theses) figuratively "lives" from this twofold meaning because the notion not only highlights simultaneously the productive tension between that two poles but brings to expression that the settling and shaping of this tension is essentially that what governance of science and technology needs to achieve.

17 Cf., among others, Grunwald 2004, who highlights the "need for reflexivity and learning at the interface between science and society".

18 For the original context of resilience cf. Holling 1973, 1994; in contrast to Morone/Woodhouse 1986 I prefer to take prevention and resilience as complementary strategies instead of oppositional alternatives.

19 For a more elaborated and proven concept cf. the BBC-model (from Janos Bogardi, Jörn Birkmann and Omar Cardona) as described in Birkmann/Wisner 2006, especially p. 22 and fig. 8. That model also links vulnerability explicitly to three spheres of sustainability, instead of four, like in my approach, which nevertheless has come to coinciding findings despite its independent development. The BBC-model is based on theoretical considerations, i.e. how social, economical and environmental dimensions of human security can be integrated with existing hazard and risk concepts. It follows the paradigm shift from a hazard-orientated research towards integrative risk reduction perspective as discussed by Bogardi/Birkmann 2004; for a resume cf. Birkmann 2006. 
And that means, more politically spoken: Modernity becomes the more vulnerable, the less it succeeds to perform an excellent governance of science and technology.

Betrayed like this it makes no sense any more to claim that modernity quasi automatically becomes more and more exposed to "global risks" that are meant to be essentially "out of control" 20 or to promote the suggestion that it might be sufficient to blame (cf. Douglas/Wildavsky 1988) certain social actors (like industry) or particular social activities (like technology). Instead, this view recommends to recognize the apparent problems as outcomes emerging from inherent qualities of modern societies that are deeply rooted in their genesis, dispersed over the whole societal system and embracing either its material as well as its mental infrastructure ${ }^{21}$. Evoking an image where modernity is inevitably drifting into some kind of terminal catastrophe is not only a doubtful legitimization of the widespread feeling of living within a "State of Fear" (Crichton 2004) but draws away attention, energies and resources from still existing opportunities to better the situation, to solve the crisis and to redirect the development. In contrast, that image involuntarily favors some species of common sense fatalism.

The second general thesis can be explained as follows: The higher the (grade of) sustainability of the four dimensions, the lower their (grade of) vulnerability, and the higher is simultaneously their ability for prevention and resilience, in order to limit occurring damages or impairments in their scale, to reduce them in their probability of taking place or "to get up again", that is to overcome vast consequences and to recover from severe events. In reverse that means: The greater the "non-sustainability", the comparatively more vulnerable, less prevention-capable and resilient is a society. From this follows: All what we are doing particularly with the instruments of technology assessment and the more general governance actions - in order to utilize the techno-scientific knowledge "constructively", in order to design techno-industrial systems favorably with regard to their consequences for the sustainability of the four dimensions, is a contribution to reduce the vulnerability of a society and to increase simultaneously its faculties for prevention and resilience. In reverse it is valid, unfortunately, that modernity becomes the more vulnerable, the less it succeeds, to do exactly this.

For the illustration of these theses serves the notice, that a decentralized system of supplying electric power with regenerative energies is more favorable with regard to some dimensions of sustainability than a few major mega-power-plants with overland transmission lines. Moreover, the decentralized system is more resilient, could therefore be repaired after catastrophes faster and with simpler means, while in reverse the mega-power-plants (above all naturally that of nuclear type) could be a much more worthwhile target for terror actions, than, for instance, a wind energy park. ${ }^{22}$

After we have so far examined the shaping problem (of the scientific-technological progress) so to say "from inside" (Chapter 2) and "from outside" (Chapter 3), it should now be tackled (in Chapter 4) in relation to the guiding model of "sustainability".

${ }^{20}$ Cf. Winner 1977, for the ancient "technics out of control"-theme that seems to be an "evergreen" of political thought.

21 One of the characteristics of that mental infrastructure most important here are the open horizons of uncertainties that are - for better or for worse - accompanying the wide space for individual selfrealization, experimental endeavors, creative explorations and free entrepreneurship that was opened up in modern societies; cf. Giddens 1990.

22 Cf. also the recommendations of Perrow, who emphasized that "instead of focusing on preventing disasters and coping with their aftermath - which we must continue to do - we should reduce the size of vulnerable targets" (Perrow 2007, p. 1, emphasis in the original). 


\section{Sustainable Development}

\subsection{Conventional Model of Wealth and Essentials of SD}

Sustainable Development (SD) is no "utopian" vision - it is a "pragmatic" concept. SD offends nobody, can be proclaimed everywhere, establishes, however, a tension arch that is distinct enough in order to be able to re-direct the on-going practice.

Departing from the 1987 published results of the "World Commission for Environment and Development" (also well-known as "Brundtland-Report") we can observe in politics, economy, science and the public that there is a spreading and growing insight, that the conventional model of growth and prosperity of the "western hemisphere" 23 could neither be temporally prolonged forever, not even for some centuries, nor could it be spatially expanded for all, that is, for the whole planet. It hurts either on the input- as on the output-side upon limitations, in form of shortening resources (that get increasingly expensive) and the finite or exhausted charging capacities of ecological systems (cf. WCED 1987).

"Sustainable Development", the new paradigm suggested by the commission, aims consequently at guaranteeing the economic development ability forever (leastwise virtually), by coupling it with the moment of the preservation of the ecological environment and its usability. ${ }^{24}$ The question "how" both moments could be combined with each other in order to achieve exactly this in practice, does not answer the guiding model, however.

\subsection{Third General Thesis and its Explication}

Thereby we are moving to the third general thesis. It says: The re-direction of a system that is developing non-sustainable is in need of the constructive shaping of the scientifictechnological progress! And more politically spoken that means: The governance of science and technology is of crucial importance for entering a future-capable and durable pathway of societal (or even civilizational) development.

23 This model has been for long the paradigm for the efforts of developing and threshold countries because it raises the suggestive idea, that it might be sufficient to copy its instructions in order to realize the same successful strategy of creating common wealth by forced industrialization within a scenario of a catch-up modernization of their economies and administrations.

${ }^{24}$ Nevertheless, there do exist some diverging interpretations of this very idea that are often distinguished as "strong" or "weak" sustainability; cf., e.g., Neumayer 2003. 
Figure 3: $\quad$ Sustainable Development and Problems of Governance

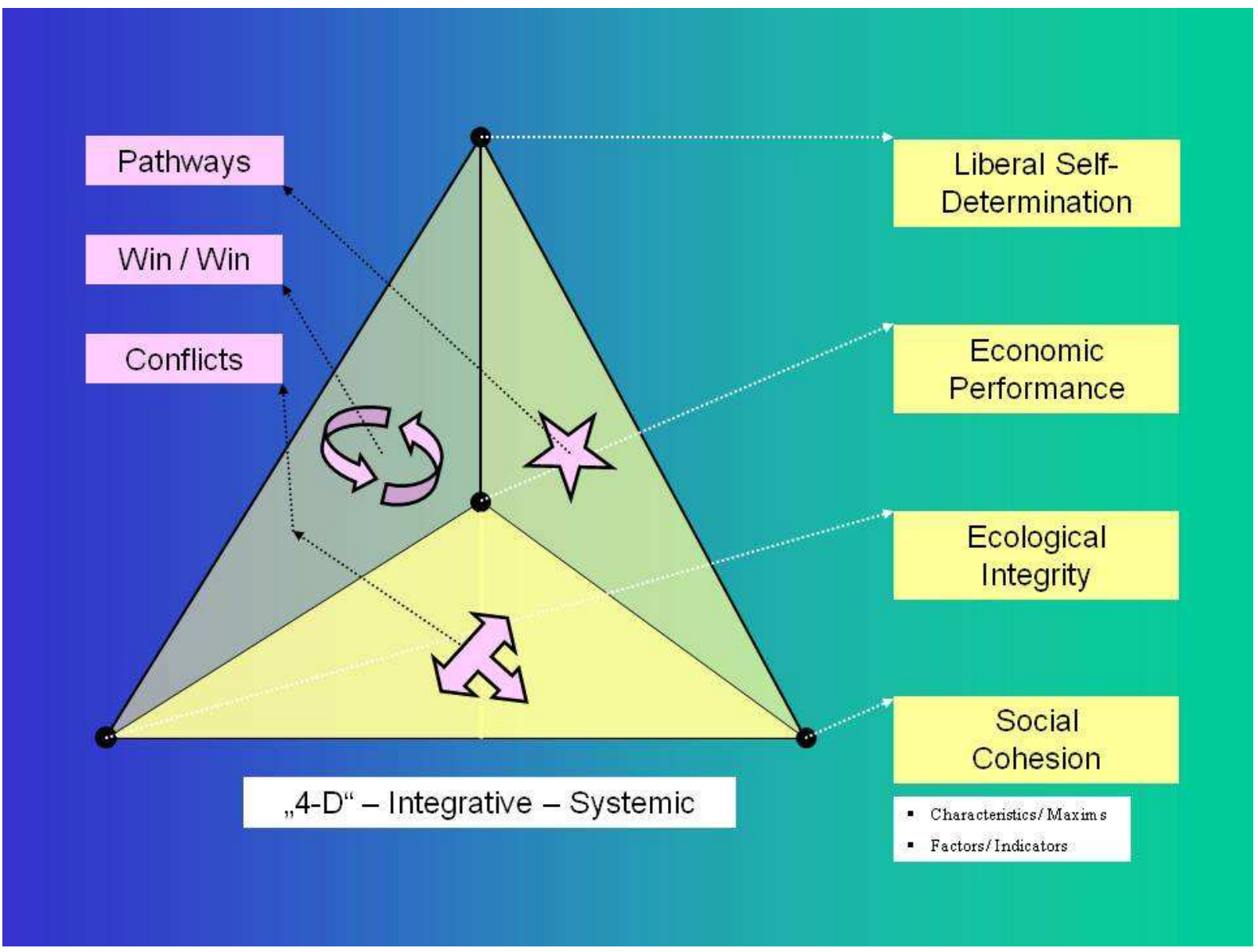

Author's archive

Essentially, as illustrated in Figure 3, the third general thesis can be explained as follows: The guiding model "sustainable development" unfolds its very sense of promoting some "futurecapable" "development" under no circumstances in some "only" environment-related interpretation (aiming at its "protection") just as little, than in some interpretation that is „only" related to social affairs (interested in questions of the "distribution of wealth" 25 ), but with some (1.) multi-dimensional, (2.) integrative and (3.) systemic understanding (cf., e.g., Grunwald 2005; Grunwald et al 2001; Kopfmüller et al. 2001), that is by using a concept that

(1) takes equally serious environmental, economic, socio-cultural and political-institutional problem clusters and requests;

(2) does not comprehend the optimization of the common welfare as some kind of zero-sum game of (more or less) justified distributions of the produced prosperity, but instead as some kind of positive-sum game, in which variant contributions are to be accumulated dynamically, without one target of optimization being ignored or neglected in favor of any other one;

(3) must be suitable for the purpose, not only to register interactions and target conflicts between the dimensions, but to analyze them with a view to possible win/winconstellations, positive synergies und dynamically stabilizing pathways of development.

Such a concept becomes all the more necessary as it is a matter of fact that "if all goes on like always", the delicious "cake" of wealth will not remain equally great but must shrink. That is like that, because our society represents a system whose steady state is that of accelerating

${ }^{25}$ For some review of the concept of social sustainability cf. Littig/Grießler 2005. 
"non-sustainable" processes of development. ${ }^{26}$ "To redirect" this system is nevertheless possible, above all by using the means of shaping the scientific-technological progress (for example with help of combined efficiency-, sufficiency- and consistency-strategies; cf. Huber 2000; Walz/Kuhlmann 2005) - but there is no way that would allow simply "to stopping" it.

Sustainable development, in terms of its dependency on knowledge and communication, consequently involves many requirements, because it is considerably more demanding than any non-sustainable path of progression. The reasons for this are, among other things:

(1) Systematically optimising societal use, i.e. including social and ecological "costs" of the budgeting in the calculations and decision-making processes of the particular economic units and social actors instead of selectively maximising it, requires greater scientific and technical knowledge, but, above all, also considerably more contextual knowledge, and more intensive and extensive information, communication and negotiation processes between a growing number of units and actors taking part or affected.

(2) Finding solutions for social problems that do justice to the complete set of the diverse rules of sustainable development (as represented e. g. in the "Integrative Approach" of the "Hermann von Helmholtz Community of German Research Centres" ${ }^{, 27}$ ) and consider all dimensions of sustainability in terms of their individual characteristics and peculiarities, is a highly coordinated process, which, for its part, demands in each case for one's own knowledge that it should be considered, communicated and put to the most diverse tests to the same extent as that of other social actors.

(3) The depth of intervention and consequence effectiveness of industrial activities in the structure and processes of nature grown out of industrial-technological development is only the other side of the coin; the change in form of ecological consequences finds its equivalent in the social consequences; for these, too, the temporal and spatial expansion, shift and change in emphasizing consequences of decisions is characteristic, as well as the confused, uncertain scattering of probabilities and risks; to comply with this development, to assess it and to even be able to properly regulate it, demands a corresponding intensification and acceleration of the acquisition of knowledge and its communicative distribution and imparting.

(4) Innovation cycles, as for instance the one of coal and steel, of electric engines, of petrochemical processes, etc or that of ICT, BGT and MNT (as introduced in Chapter 2.4) were and are leading to far-reaching modifications of the metabolism with nature, and they were and are leading to revolutions of the economical production structures of industrial societies. These social-ecological transformation processes are characterized by modified models of stress upon environmental goods and services as well as altered clusters of use competitions and shifting distribution conflicts about them. Due to the increasing science and knowledge dependency of technological-industrial innovations, also the conditions of the possibility for the identification and regulation of their social and ecological results become increasingly knowledge-dependent.

Having considered the question of the "how" of the shaping of the scientific-technological progress in three different respects, (in Chapter 2) departing from the options and consequences, that progress produces itself, (in Chapter 3) by means of the requirements, that are produced by the complex vulnerability of modern society, and (in the just finished Chapter 4) with regard to its suitability for implementing the alternate course of sustainable development, we are coming now (in Chapter 5) finally to speak about the ,instruments“, that

26 According to the assessment of lots of experts, we are actually doing nothing more than reducing the acceleration and are far from becoming slower or to reach the turning-point where processes of sustainable development would be generally supported by the momentum of the whole system.

27 Cf. Kopfmüller et al. 2001, where this integrative approach is formulated. 
are supposed to help us to deal with the problem of "how" it might be possible to shape science and technology as best as possible, namely the more general governance approach in connection with a more particular concept of technology assessment.

\section{Improving Governance by Integrative Technology Assessment}

Essentially the task of governing ${ }^{28}$ and doing the governance of global risks is for a notable part identical with that of governing or organizing the governance of science and technology (cf., among others, Petschow et al. 2005; Renn 2008; Renn/Walker 2008; Voss et al. 2006). This argument is reasonable, because the latter one constitutes the most important factor in order to influence the whole process of societal shaping of the techno-industrial progress including the consequences, uncertainties and risks that are accompanying and following this development - in an active and intentional way according to principles like, e.g., the one of sustainable development.

Regarding the elements for shaping the outcomes of science and technology there are, in general, two indispensible kinds of action: (1.) forecasting of developments, and (2.) evaluation of choices. Both are of crucial importance for the enhancement of decision-making procedures, and that is, on its part, a precondition for shaping the scientific-technological progress effectively (cf. Funtowicz/Ravetz 1992; Rosa 1988). In order to do so, we have to ask either for the expertise of academics and professionals (top down) because of the considerable (and still growing) knowledge-dependency, as well as for the participation of citizens (bottom up) because of the diversity of value-orientations. ${ }^{29}$

The importance of technology assessment as a requirement for a successful governance of science and technology is more than evident, especially whilst taking into account the accelerating speed of the techno-scientific development. Consequently the on-going work of technology assessment needs to have approaches, concepts and models that should be getting more powerful together with the expanding tasks TA is confronted with (cf. Grunwald 2010). Therefore, I would like to introduce finally some framework concept that tries to take into account all the factors tackled so far.

\subsection{Guidelines for an Integrated TA}

Under "Integrative Technology Assessment" (ITA) I understand basically, that the dimensions of the environmental, economic, socio-cultural and political-institutional conditions and consequences of technologies are dealt with systematically, and in connection with some four-dimensional, integrative and systemic concept of sustainable development, which, as an analytically enriched "civilizational guiding-model", provides an excellent framework for some differentiating and balancing and therefore well-justified evaluation of "options for progress" (at least in so far as they are mediated by science and technology). ${ }^{30}$

28 The most significant difference between both of them is, that governance includes the participation of citizens also in decision-making processes whereas governing, that is the performance of political authorities, is dependent on citizens participation in the representative way only; cf. also the common difference between politics and policy; more characteristics are discussed by Türke 2008.

29 As a consequence of the overlapping processes of globalization and individualization we also face growing multiplicity in cultural orientations, value-judgments and ethical preferences; cf. the implications of "networked individualism" as described by Manuel Castells (cf. Castells 2001; cf. also Bora/Hausendorf 2006; Ladikas 2009).

${ }^{30}$ Understanding the complexity of different systems as well as analyzing the interactions between them (cf., e.g., Holling 2001) is, in this sense, a precondition for gaining the abilities that are necessary in order to navigate successfully towards sustainable development (cf., e.g., Hjorth/Bagheri 2006). 
ITA, as presented here, is only a framework concept that tries to offer inspiring heuristics, not an operative model that gives precise methodological prescriptions of how to carry out TA procedures and investigations. ${ }^{31}$ From its design it is predestined to approach the ability to embrace different TA-models, which for their part prescribe different modes of how to realize the work to be done methodologically correct and effective. The objective of its proposal is therefore nothing more - but also nothing less - than to contribute to the expanding discourse on the conceptual foundations of TA.

In order to prevent misunderstandings: If sustainability is constitutive for a concept of ITA, then this requires dealing with all four dimensions of sustainable development with equal attention ... in the framework concept (!) - but not in every single project. If therefore in some project, for instance, the focus is on investigating "electronic governance", then, obviously, political-institutional issues are standing in the foreground. The advantage of such a framework concept is, to be prepared for reacting in a flexible but competent way on particular calls for project funding and emerging demands for investigating issues that are on the ever-changing public agenda, without having to refrain from processing the results of various projects also synthetically, in order to build up one's own theoretical, methodological and professional capacities for the acquisition and elaboration of further projects "step by step".

ITA, a "holistic" concept, requires more than an expansion of a multitude of single research areas. ITA cannot thrive by doing science studies or innovation research (that is by analyzing probable or desirable innovations with the intention of paving the way for the realization of economic benefits by their promotion). In order to fulfill its cross-sectional task, TA must - even for complexity reasons (cf. Bechmann et al. 2007) - transcendent an understanding of its subject that is "only" oriented to economics and the social sciences. TA can moreover not achieve its ends simply by "co-opting" natural scientists' and engineering competencies. Instead, the decisive point is, from an inter- and transdisciplinary comprehension (cf. Decker/Grunwald 2001; Gallopín et al. 2001), the possibility to depart from different disciplinary backgrounds and similarly developed professional competencies in order to analyze and assess the heterogenous conditions, consequences, and choices of technology, and to enhance these working perspectives (or strategies of knowledge elaboration and capacity building) mutually within a common framework for problem-driven investigation. Integrative TA is therefore extraordinarily dependent on teamwork.

In the purview of ITA the central task is: (1.) to combine competencies, namely above all those of the various sciences, and, moreover, those of professionals from several fields of practice, and those of citizens or so-called lay-persons; (2.) to process problems departing from the changing perspectives of science, economy, politics and the public; and (3.) to provide solutions, approaches and criteria, in order to advise societal actors (both in politics and policy).

Not least comes into play, however, a function that matters concerning the sciences themselves: namely to achieve a contribution to their consolidation. This is all the more important as any TA institution, be it an academy of science or university, a (public) research centre or (private) enterprise, must have a vital interest in its own consolidation, as well to its outside, in front of the public, the economy, and the politics, as to its inside, in the relationship of its scientific disciplines and its particular institutes or working-units.

For ITA the research field of the "new" "key technologies" is of utmost importance, because they are particularly aligned to or generally associated with considerable expectations of growth and progress. Their importance from the viewpoint of a sustainable development of

31 For some similar endeavor cf. Liebert/Schmidt 2010; a well thought-out idea of how to direct our attention comes from Decker/Fleischer 2010; cf. also Schot/Rip 1997. 
economy and society is thereby not at all to estimate lesser, than under the pre-sign of a conventional course of modernization (cf., among others, Fleischer et al. 2001).

An important element of integrative TA is to identify and localize possible targetingconflicts that should be resolved or settled, and probable win/win-constellations that should be promoted because they are promising some concrete "added value". An example of this, that simultaneously makes us recognize the often conflict-laden character of the requests that TA becomes more and more confronted with in the field of the "new" key technologies, is the opportunity to substitute processes of the chemical synthesis of substances by biotechnological procedures (cf. Willke/Vorlop 2004). Following the economic principle of "creative destruction" thereby comes under pressure an "older" industrial branch - including its jobs - for the benefit of a "younger" one that is promising more prosperity (cf. Reinert/Reinert 2006). Considered ecologically, these procedures are offering ambivalent opportunities. On the one side, they indeed do have potentials for ameliorating the charge of the environment, either regarding the side of their input (referring to the grade of making use of energetic and material resources), and also concerning the side of their output (with regard to the possible reduction in the release of environmental chemicals and mass pollutants). On the other side are to register, however, the risks and uncertainties of the release of bio-active substances and trans-geneous organisms.

ITA offers no panacea. It can process, however, highly complex problem bundles, whose judgment - as just shown - is normally leading to complications in an organized and differentiating manner, that is refined according to the distinct purposes of decision-making. ${ }^{32}$

\subsection{Fourth General Thesis, and its Explication}

Thereby we are coming to the fourth, concluding, general thesis. It says: In order to master the challenges, (the shaping of) science and technology becomes confronted with by the present problems, it is essential to make use of a framework concept like ITA!

And traduced into a more political language, that is to say that the governance of science and technology could not be done sufficiently well without approaches that allow for overview and orientation. The task of regulating and optimizing the techno-scientific and (post-)industrial development that is currently creating the options of the shape and configuration of our societal and environmental future cannot be achieved successfully while performing no more than some kind of "muddling through"-strategy. ${ }^{33}$ Because of the need to develop applicable strategies in order to restore and maintain a future-capable pattern of development there does exist a great demand for integrated approaches and wide framework concepts.

The fourth general thesis, as indicated by Figure 4, can be explained as follows: "ITA" is an instructive approach that is meant to be used for opening up the problems of the increasing knowledge and science dependency (I.) of the complex vulnerability of modern societies (II.) and of the practical achievability of sustainable development (III.), in order to structure, as optimal as possible, the preparation, realization and reworking of TA-projects and -procedures aiming at informing not only governing bodies and affiliated parties but all kinds of social actors (including NGOs) that participate in governance activities.

32 Another requisite to foster "sustainable" decision-making procedures is strengthening foresight and scenario approaches especially with reference to the mentioned problem of growing uncertainties; cf., among others, Guimaraes Pereira et al. 2007; Newman 2006; Stirling 2006.

33 With reference to the further implications of the "muddling through"-strategy it should be said that "incrementalism", as the underlying political steering idea this strategy is based upon, is endangering the realization of long-term goals because of its prevalence for giving attention to short-term goals. 
Figure 4: $\quad$ Integrated Technology Assessment and its Challenges

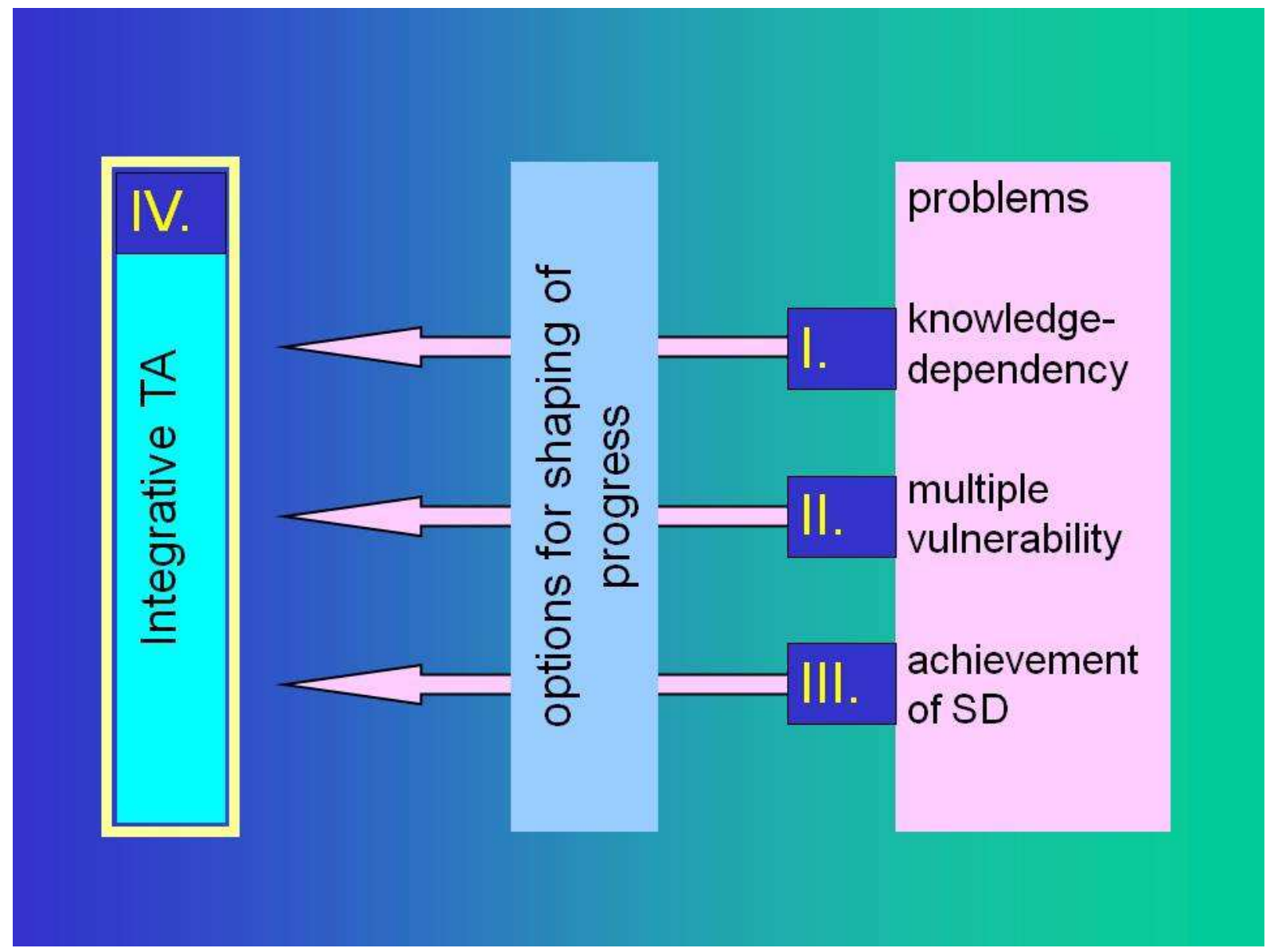

Author's archive

A little more detailed, these three points indicate the following claims:

(I) ITA provides for both, for an analytical separation of the shaping conditions and implementation consequences of the scientific-technological progress (with reference to economic, ecological, socio-cultural and political-institutional interdependencies), as well as for the synthesis of the investigation results (with regard to key technologies, innovation cycles and industrial society transformations).

(II) ITA provides for to open up questions of the shaping of the scientific-technological progress in the interrelationship of hazards, vulnerability, risks, prevention and resilience, problem-sensitive and solution-oriented: ... on the micro-level of single humans or households that could be affected, on the meso-level of single communities, companies, social systems as well as on the macro-level of complete societies.

(III) ITA provides for (re)directing innovation processes to the resolution or settling of target conflicts, to the utilization of win-win-constellations and to walking along stable pathways of progressive development.

\section{Outlook}

With the new millennium we face tremendous challenges. Limited actions like governance of science and technology in general, and technology assessment in particular, are hardly sufficient in order to master them - but it is, however, necessary to contribute all what they can do, in order to provide for some constructive shaping of the scientific-technological progress. I would like to close therefore with a saying of Antoine de St. Exupéry: "One must require from everyone what he could achieve!" 


\section{References}

Abramovitz, J.; Starke, L. (eds.) (2001): Unnatural Disasters. Washington/D.C. (Worldwatch Institute)

Adriaanse, A.; Bringezu, St.; Hammond, A.; Moriguchi, Y.; Rodenburg, E.; Rogich, D.; Schütz, H. (1997): Resource Flows. The Material Basis of Industrial Economies. Washington, D.C. (World Resource Institute)

Ayres, R. U.; Simonis, U. E. (eds.) (1992): Industrial Metabolism. Restructuring for Sustainable Development. Tokyo/New York/Paris

Baker, S. (2000): The European Union. Integration, Competition, Growth - and Sustainability. In: Lafferty, W. M.; Meadowcroft, J. (eds.): Implementing Sustainable Development. Strategies and Initiatives in High Consumption Societies. Oxford, pp. 303-336

Banse, G.; Metzner-Szigeth, A. (2011): Cultural Diversity and New Media - their Interaction as an Element of European Integration. Elaborating an European Research Network. In: Rothkegel, A.; Ruda, S. (eds.): Communication on and via Technology. Berlin (in print)

Barletta, W. A. (2010): Cyberwar or Cyber-Terrorism. The Attack on Estonia. In: Westby, J. R.; Wegener, H.; Barletta, W. (eds.): Rights and Responsibilities in Cyberspace. Balancing the Need for Security and Liberty. New York (East West Institute)/Geneva (World Federation of Scientists), pp. 1115. - URL: http://www.ewi.info/system/files/Rights_and_Responsibilties_Web.pdf

Barnett, V. (1998): Kondratiev and the Dynamics of Economic Development. London

Barton, J. E.; Dracup, M. (2000): Genetically Modified Crops and the Environment. In: Agronomy Journal, Vol. 92, No. 4, pp. 797-803. - URL: http://dx.doi.org/10.2134/agronj2000.924797x

Bechmann, G.; Decker, M.; Fiedeler, U.; Krings, B.-J. (2007): TA in a Complex World. In: International Journal of Foresight and Innovation Policy, Vol. 3, No. 1, pp. 6-27

Beck, U. (1992): The Risk Society. Towards a New Modernity. London

Beck, U. (1999a): What is Globalization? Cambridge

Beck, U. (1999b): World Risk Society. Cambridge

Beck, U.; Giddens, A.; Lash, S. (1994): Reflexive Modernization. Politics, Tradition and Aesthetics in the Modern Social Order. Cambridge

Becker, E.; Jahn, Th.; Stiess, I. (1999): Exploring Uncommon Ground. Sustainability and the Social Sciences. In: Becker, E.; Jahn, Th. (eds.): Sustainability and the Social Sciences. A Cross-Disciplinary Approach Integrating Environmental Considerations into Theoretical Reorientation. London, pp. 1-22

Becker, E.; Jahn, Th.; Schramm, E.; Hummel, D.; Stiess, I. (2000): Social-Ecological Research. Conceptual Framework for a New Funding Policy (Synopsis of the Report for the German Federal Ministry of Education and Research). Frankfurt am Main (ISOE)

Beer, T.; Ismail-Zadeh, A. (eds.) (2003): Risk Science and Sustainability. Science for Reduction of Risk and Sustainable Development of Society. Dordrecht a.o.

Berting, J. (2006): Europe: a Heritage, a Challenge, a Promise. Delft

Bijker, W. E. (2006): The Vulnerability of Technological Culture. In: Nowotny, H. (ed.): Cultures of Technology and the Quest for Innovation. New York, pp. 52-69. - URL: http://arno.unimaas.nl/show.cgi?fid=14863

Bijker, W. E.; Hughes, T. P.; Pinch, T. J. (eds.) (1987): The Social Construction of Technological Systems. New Directions in the Sociology and History of Technology. Cambridge, MA/London

Birkmann, J. (2006): Measuring Vulnerability to Promote Disaster-resilient Societies. Conceptual Frameworks and Definitions. In: Birkmann, J. (2006): Measuring Vulnerability to Natural Hazards. Towards Disaster Resilient Societies. New Delhi, pp. 9-54 
Birkmann, J.; Wisner, B. (2006): Measuring the Un-Measurable. The Challenge of Vulnerability. Bonn. - URL: http://www.ehs.unu.edu/file/get/3962

Bogardi, J.; Birkmann, J. (2004): Vulnerability Assessment. The First Step Towards Sustainable Risk Reduction. In: Malzahn, D.; Plapp, T. (eds.): Disasters and Society. From Hazard Assessment to Risk Reduction. Berlin, pp. 75-82

Bora, A.; Hausendorf, H. (2006): Participatory Science Governance Revisited. Normative Expectations Versus Empirical Evidence. In: Science and Public Policy, Vol. 33, No. 7, pp. 478-488

Bresnahana, T. F.; Trajtenberg, M. (1995): General Purpose Technologies "Engines of growth"? In: Journal of Econometrics, Vol. 65, No. 1, January 1995, pp. 83-108. - URL: http://dx.doi.org/10.1016/0304-4076(94)01598-T

Cassier, M. (2002): Private Property, Collective Property, and Public Property in the Age of Genomics. In: International Social Science Journal, Vol. 171, pp. 83-98

Castells, M. (1996): The Information Age: Economy, Society and Culture. Vol. I: The Rise of the Network Society. Malden/Oxford

Castells, M. (2001): The Internet Galaxy. Reflections on the Internet, Business, and Society. Oxford

Casti, J. L. (1994): Complexification. New York

Chambers, R. (1989): Editorial Introduction: Vulnerability, Coping and Policy. In: IDS Bulletin, Vol. 20, No. 2, pp.1-7

Crichton, M. (2004): State of Fear. London

David, P. A. (2001): Tragedy of the Public Knowledge "Commons"? Global Science, Intellectual Property and the Digital Technology Boomerang. In: Research Memoranda, Maastricht Economic Research Institute on Innovation and Technology (MERIT). - URL: http://edocs.ub.unimaas.nl/loader/file.asp?id=208

Decker, Michael (ed.) (2001): Interdisciplinarity in Technology Assessment. Implementation and its Chances and Limits. Berlin (Springer)

Decker, M.; Fleischer, Th. (2010): When Should there be which Kind of Technology Assessment? A Plea for a Strictly Problem-oriented Approach from the Very Outset. In: Poiesis \& Praxis. International Journal of Technology Assessment and Ethics of Science, No. 7, pp. 117-133

Decker, M.; Grunwald, A. (2001): Rational Technology Assessment as Interdisciplinary Research. In: Decker, M. (ed.): Interdisciplinarity in Technology Assessment. Implementation and its Chances and Limits. Berlin a.o., pp. 33-60

Douglas, M.; Wildavsky, A. (1988): Risk and Culture. $2^{\text {nd }}$ ed. Berkley, CA/Los Angeles, CA/London

ETAG - European Technology Assessment Group (2006): Technology Assessment on Converging Technologies. Brussels (European Parliament)

Fakete, A. (2010): Assessment of Social Vulnerability for River-Floods in Germany. Bonn (University). Doctoral Thesis. - URL: http://hss.ulb.uni-bonn.de:90/2010/2004/2004.pdf

Fischer-Kowalski, M. (1997): Society's Metabolism. On the Childhood and Adolescence of a Rising Conceptual Star. In: Redclift, M.; Woodgate, G. (eds.): The International Handbook of Environmental Sociology. Cheltenham, pp. 119-137

Fischer-Kowalski, M.; Haberl, H. (1993): Metabolism and Colonisation. Modes of Production and the Physical Exchange between Societies and Nature. In: Innovation in Social Science Research, Vol. 6, pp. $415-442$

Fisher, H. W. (1994): Response to Disaster: Fact Versus Fiction and Its Perpetuation. The Sociology of Disaster. Lanham, MD 
Fleischer, T.; Fugger, W.-D.; Grunwald, A.; Karger, C.; Poppenborg, A. (2001): Nachhaltigkeitspotenziale von Schlüsseltechnologien. In: Grunwald, A.; Coenen, R.; Nitsch, J.; Sydow, A.; Wiedemann, P. (eds.): Forschungswerkstatt Nachhaltigkeit. Auf dem Weg zur Diagnose und Therapie von Nachhaltigkeitsdefiziten. Berlin, pp. 267-290 (in German)

Freeman, Ch.; Louçã, F. (2001): As Time Goes By. From the Industrial Revolution to the Information Revolution. Oxford

Funtowicz, S. O.; Ravetz, J. R. (1992): Three Types of Risk Assessment and the Emergence of PostNormal Science. In: Krimsky, Sh.; Golding, D. (eds.): Social Theories of Risk. Westport, CT/London, pp. 251-273

Gallopín, G. C.; Funtowicz, S. O.; O’Connor, M.; Ravetz, J. (2001): Science for the Twenty-First Century: From Social Contract to the Scientific Core. In: International Social Science Journal, Vol. 53, No. 168 , pp. 219-229

Giddens, A. (1990) The Consequences of Modernity. Stanford, CA

Giddens, A. (2009): The Politics of Climate Change. Cambridge

Godin, B. (2006): The Linear Model of Innovation. The Historical Construction of an Analytical Frame-work. In: Science, Technology \& Human Values, Vol. 31, pp. 639-667

Graham, J.; Amos, B.; Plumptre, T. (2003): Principles for Good Governance in the 21st Century.

Policy Brief, No. 15 (Institute on Governance, Ottawa). - URL: http://iog.ca/sites/iog/files/policybrief15_0.pdf

Grossmann, W. D. (2001): Entwicklungsstrategien in der Informationsgesellschaft. Mensch, Wirtschaft und Umwelt. Berlin a.o. (in German)

Grunwald, A. (2004): Strategic Knowledge for Sustainable Development: The Need for Reflexivity and Learning at the Interface Between Science and Society. In: International Journal for Foresight and Innovation Policy, Vol. 1, No. 1/2, pp. 150-167. - URL: http://dx.doi.org/10.1504/IJFIP.2004.004619

Grunwald, A. (2005): Rationality in an Uncertain World. The Vision of Sustainable Development as an Adequate Answer? In: Banse, G.; Hronszky, I.; Nelson, G. (eds.): Rationality in an Uncertain World. Berlin, pp. 11-35

Grunwald, A. (2007): Converging Technologies: Visions, Increased Contingencies of the conditio humana, and Search for Orientation. In: Futures, Vol. 39, No. 4, pp. 380-392. - URL: http://dx.doi.org/10.1016/j.futures.2006.08.001

Grunwald, A. (2010): Technikfolgenabschätzung. Eine Einführung. $2^{\text {nd }}$, completely rev. and ext. ed. Berlin (in German)

Grunwald, A.; Coenen, R.; Nitsch, J.; Sydow, A.; Wiedemann, P. (eds.) (2001): Forschungswerkstatt Nachhaltigkeit. Auf dem Weg zur Diagnose und Therapie von Nachhaltigkeitsdefiziten. Berlin (in German)

Grunwald, A.; Grin, J. (eds.) (1999): Vision Assessment. Shaping Technology in $21^{\text {st }}$ Century Society. Berlin a.o.

Guimaraes Pereira, A.; Schomberg, R. von; Funtowicz, S. (2007): Foresight Knowledge Assessment. In: International Journal of Foresight and Innovation Policy, Vol. 3, No. 1, pp. 53-27. - URL: http://dx.doi.org/10.1504/IJFIP.2007.011421

Haberl, H.; Fischer-Kowalski, M.; Krausmann, F.; Weisz, H.; Winiwarter, V. (2004): Progress Towards Sustainability? What the Conceptual Framework of Material and Energy Flow Accounting (MEFA) Can Offer. In: Land Use Policy, Vol. 21, No. 3 (July), pp. 199-213. - URL: http://dx.doi.org/10.1016/j.landusepol.2003.10.013

Held, D. (ed.) (2000): A Globalizing World? Culture, Economics, Politics. London 
Heng, Y.-K.; McDonagh, K. (2009): Risk, Global Governance and Security. The Other War on Terror. Milton Park

Hinterberger, F.; Luks, F.; Schmidt-Bleek, F. (1997): Material Flows vs. "Natural Capital". What Makes an Economy Sustainable? In: Ecological Economics, Vol. 23, No. 1, pp. 1-14

Hjorth, P.; Bagheri, A. (2006): Navigating Towards Sustainable Development. A System Dynamics Approach. In: Futures, Vol. 38, No. 1, pp. 74-92. - URL: http://dx.doi.org/10.1016/j.futures.2005.04.005

Hodgson, G. M. (2000): Socio-economic Consequences of the Advance of Complexity and Knowledge. In: OECD - Organisation for Economic Co-operation and Development (ed.) (2000): The Creative Society of the 21st Century. Paris (OECD), pp. 89-112

Holling, Crawford Stanley (1973): Resilience and Stability of Ecological Systems. In: Annual Review of Ecology and Systematics, Vol. 4, 1973, pp. 1-23

Holling, C. St. (1994): Simplifying the Complex. The Paradigms of Ecological Function and Structure. In: Futures, Vol. 26, No. 6, pp. 598-609

Holling, C. St. (2001): Understanding the Complexity of Economic, Ecological, and Social Systems. In: Ecosystems, Vol. 4, No. 5, pp. 390-405

Huber, J. (2000): Towards Industrial Ecology. Sustainable Development as a Concept of Ecological Modernization. In: Andersen, M.; Massa, I. (eds.): Ecological Modernization. Journal of Environmental Policy and Planning, Special Issue 2, pp. 269-285

IPCC - Intergovernmental Panel on Climate Change (2007): Climate Change 2007. Synthesis Report. Contribution of Working Groups I, II and III to the $4^{\text {th }}$ Assessment Report of the Intergovernmental Panel on Climate Change (Core Writing Team, Pachauri, R. K.; Reisinger, A. eds.). Geneva (IPCC). URL: http://www.ipcc.ch/pdf/assessment-report/ar4/syr/ar4_syr.pdf

Jaeger, C. C. (1994): Taming the Dragon. Transforming Economic Institutions in the Face of Global Change. Amsterdam/Singapore

Jaeger, C. C. (1998): Risk Management and Integrated Assessment. In: Environmental Modeling and Assessment, Vol. 3, No. 4, pp. 211-225

Joerges, B. (1996): Large Technical Systems and the Discourse of Complexity. In: Ingelstam, L. (ed.): Complex Technical Systems. Stockholm (Swedish Council for Planning and Coordination of Research), pp. 55-72

Johnston, P. (ed.) (2002): Visions and Roadmaps for Sustainable Development in a Networked Knowledge Society. Report of a Workshop Co-chaired by the Presidents of the Brussels EU-Chapter of the Club of Rome and the "Factor 10 Institute". Brussels (European Commission, DG - Information Society Technologies). - URL: http://www.clubofrome.at/cor-eu/archive/dl_seminar.pdf

Kleine, A. (2009): Operationalisierung einer Nachhaltigkeitsstrategie. Ökologie, Ökonomie und Soziales Integrieren. Wiesbaden (in German)

Klinke, A.; Renn, O. (2002): A New Approach to Risk-Evaluation and Management. Risk-Based, Precaution-Based, and Discourse-Based Strategies. In: Risk Analysis, Vol. 22, No. 6, pp. 1071-1094. URL:

http://directory.cip.management.dal.ca/publications/A\%20new\%20approach\%20to\%20risk\%20evalua tion\%20and\%20management.pdf

Kondratieff, N. D. (1926): Die langen Wellen der Konjunktur. In: Archiv für Sozialwissenschaft und Sozialpolitik, Vol. 56, pp. 573-609 (in German)

Kopfmüller, J.; Brandl, V.; Jörissen, J.; Paetau, M.; Banse, G.; Coenen, R.; Grunwald, A. (2001): Nachhaltige Entwicklung integrativ betrachtet. Konstitutive Elemente, Regeln, Indikatoren. Berlin (in German) 
Ladikas, M. (ed.) (2009): Embedding Society in Science \& Technology Policy. European and Chinese perspectives. Luxembourg (Office for Official Publications of the European Communities). - URL: http://ec.europa.eu/research/science-society/document_library/pdf_06/european-and-chineseperspectives_en.pdf

Lash, S.; Szerszinsky, B.; Wynne, B. (1996): Risk, Environment and Modernity. Towards a New Ecology. London

Liberatore, Angela (1998): The Management of Uncertainty - Learning from Chernobyl. Amsterdam, Singapore (Gordon and Breach Publishers)

Liberatore, A.; Funtowicz, S. (eds.) (2003): Democratising Expertise, Expertising Democracy. In: Science and Public Policy, Special Issue, 30 (2), June

Liebert, W.; Schmidt, J. C. (2010): Towards a Prospective Technology Assessment. Challenges and Requirements for Technology Assessment in the Age of Technoscience. In: Poiesis \& Praxis. International Journal of Technology Assessment and Ethics of Science, Vol. 7, No. 1-2, pp. 99-116. URL: http://dx.doi.org/10.1007/s10202-010-0079-1

Lindblom, Ch. E. (1959): The Science of "Muddling Through". In: Public Administration Review, Vol. 19, pp. 79-88

Lindblom, Ch. E. (1979): Still Muddling, Not yet through. In: Public Administration Review, Vol. 39, pp. 517-526

Littig, B.; Grießler, E. (2005): Social Sustainability. A Catchword between Political Pragmatism and Social Theory. In: International Journal of Sustainable Development, Vol. 8, No. 1/2, pp. 65-79

Lubbers, R.; Koorevaar, J. (2000): Primary Globalisation, Secondary Globalisation, and the Sustainable Development Paradigm. Opposing Forces in the 21st Century. In: OECD - Organisation for Economic Co-operation and Development (ed.): The Creative Society of the 21st Century. Paris (OECD), pp. 173-190

Luhmann, N. (1989): Ecological Communication. Chicago

Mappus, St. (ed.) (2005): Erde 2.0. Technologische Innovationen als Chance für eine nachhaltige Entwicklung. Heidelberg a.o. (in German)

Masera, M. (2005): Systemic Challenges for Critical Information Infrastructure Protection. In: Kowalik, J. S.; Górski, J.; Sachenko, A. (eds.): Cyberspace Security and Defense. Research Issues. Dordrecht a.o., pp. 57-74

Masera, M.; Gheorghe, A.; Weijnen, M.; Vries, L. de (2006): Critical Infrastructures at Risk. Securing the European Electric Power System. Dordrecht a.o.

Mayhew, A. (2000): Review of Karl Polanyi "The great transformation. The Political and Economic Origins of Our Time". In: EH.Net Economic History Services, June 1. - URL: http://eh.net/bookreviews/library/polanyi

Metzner, A. (1993): Probleme sozio-ökologischer Systemtheorie. Natur und Gesellschaft in der Soziologie Luhmanns. Opladen. - URL: http://sammelpunkt.philo.at:8080/1812/ (in German)

Metzner, A. (1998): Constructions of Environmental Issues in Scientific and Public Discourse. In: Müller, F.; Leupelt, M. (eds.): Eco Targets, Goal Functions and Orientors. Berlin a.o., pp. 312-333

Metzner, A. (2002): Die Tücken der Objekte. Über die Risiken der Gesellschaft und ihre Wirklichkeit. Frankfurt am Main/New York (in German)

Metzner-Szigeth, A. (2009): Contradictory Approaches? On Realism and Constructivism in the Social Sciences Research on Risk, Technology and the Environment. In: Futures, Vol. 41, No. 2 (March), pp. 156-170. - URL: http://dx.doi.org/10.1016/j.futures.2008.09.017

Metzner-Szigeth, A. (2010): Kultur \& Technik als Medien menschlicher Selbstverwirklichung. Überlegungen zur philosophischen Anthropologie und Gesellschaftstheorie. In: Banse, G.; Grunwald, 
A. (eds.): Technik und Kultur. Bedingungs- und Beeinflussungsverhältnisse, Karlsruhe, pp. 143-162. URL: http://www.itas.fzk.de/deu/lit/2010/bagr10a.pdf (in German)

Morone, J. G.; Woodhouse, E. J. (1986): Averting Catastrophe. Strategies for Regulating Risky Technologies. Berkeley, CA

Neumayer, E. (2003): Weak versus Strong Sustainability. Exploring the Limits of Two Opposing Paradigms. Northampton, MA

Newman, L. (2006): Change, Uncertainty, and Futures of Sustainable Development. In: Futures, Vol. 38, No. 5, pp. 633-637. - URL: http://dx.doi.org/10.1016/j.futures.2005.09.011

Nordmann, A. (2004): Converging Technologies. Shaping the Future of European Societies (Report of the High Level Expert Group "Foresighting the New Technology Wave"). Brussels (European Communities)

Nowotny, H.; Scott, P.; Gibbons, M. (2001): Re-Thinking Science. Knowledge and the Public in an Age of Uncertainty. London

OECD - Organisation for Economic Co-operation and Development (2003): Emerging Risks in the 21st Century. An Agenda for Action. Paris (OECD). - URL: http://www.oecd.org/dataoecd/20/23/37944611.pdf

Orwat, C.; Grunwald, A. (2005): Informations- und Kommunikationstechnologien und nachhaltige Entwicklung. In: Mappus, St. (ed.) (2005): Erde 2.0. Technologische Innovationen als Chance für eine nachhaltige Entwicklung? Berlin a.o., pp. 242-273 (in German)

Perrow, Ch. (1984): Normal Accidents. Living with High-Risk Technologies. New York

Perrow, Ch. (2007): The Next Catastrophe. Reducing Our Vulnerabilities to Natural, Industrial, and Terrorist Disasters. New Jersey

Petschow, U.; Rosenau, J.; von Weizsäcker, E.-U. (eds.) (2005): Governance and Sustainability. Sheffield

Pidgeon, N.; O'Leary, M. (2000): Man-made Disasters. Why Technology and Organizations (Sometimes) Fail. In: Safety Science, Vol. 34, pp. 15-30. - URL: http://dx.doi.org/10.1016/S09257535(00)00004-7

Pinch, T. J. (1991): How Do We Treat Technical Uncertainty in Systems Failure? The Case of the Space Shuttle Challenger. In: La Porte, T. R. (ed.): Social Responses to Large Technical Systems. Control or Anticipation. Dordrecht, pp. 143-158

Polanyi, K. (1944): The Great Transformation. The Political and Economic Origins of Our Time. Boston ( $2^{\text {nd }}$ ed. 1957)

Reinert, H.; Reinert, E. S. (2006): Creative Destruction in Economics: Nietzsche, Sombart, Schumpeter. In: Backhaus, J.; Drechsler, W. (eds.): Friedrich Nietzsche 1844-2000. Boston, pp. 55-85

Renn, O. (2008): Risk Governance. Coping with Uncertainty in a Complex World. London

Renn, O.; Keil, F. (2008): Systemische Risiken. Versuch einer Charakterisierung. In: GAIA, Vol. 17, No. 4, pp. 349-354

Renn, O.; Walker, K. D. (eds.) (2008): Global Risk Governance. Concept and Practice Using the IRGC Framework. Dordrecht

Rissler, J.; Mellon, M. (1996): The Ecological Risks of Engineered Crops. Cambridge, MA

Robertson, R. (1995): Glocalization: Time-Space and Homogeneity-Heterogeneity. In: Featherstone, M.; Lash, S.; Robertson, R. (eds.): Global Modernities. London, pp. 25-44

Roco, M. C.; Bainbridge, W. S. (eds.) (2004): Converging Technologies for Improving Human Performance. Dordrecht 
Rosa, E. A. (1988): Metatheoretical Foundations for Post-normal Risk. In: Journal of Risk Research, Vol. 1, No. 1, pp. 15-44

Schiller, F. (2009): Linking Material and Energy Flow Analyses and Social Theory. In: Ecological Economics, Vol. 68, Issue 6 (April 15), pp. 1676-1686. - URL: http://dx.doi.org/10.1016/j.ecolecon.2008.08.017

Schomberg, R. von (2002): The Objective of Sustainable Development: Are We Coming Closer? Brussels (European Commission, DG Research)

Schot, J.; Rip, A. (1997): The Past and Future of Constructive Technology Assessment. In: Technological Forecasting and Social Change, Vol. 54, No. 2, pp. 251-268. - URL: http://dx.doi.org/10.1016/S0040-1625(96)00180-1

Solana, J. (2003): A Secure Europe in a Better World. European Security Strategy (Document proposed by the EU High Representative for the Common Foreign and Security Policy and adopted by the Heads of State and Government at the European Council in Brussels on December 12, 2003). Paris (The European Union Institute for Security Studies). - URL: http://www.iss.europa.eu/uploads/media/solanae.pdf

Souza Porto, M. F. de; Freitas, C. M. de (2003): Vulnerability and Industrial Hazards in Industrializing Countries. An Integrative Approach. In: Futures, Vol. 35, No. 7, pp. 717-736. - URL: http://dx.doi.org/10.1016/S0016-3287(03)00024-7

Spangenberg, J.; Mesicek, R.; Metzner, A.; Luks, F. (2002): Sustainability Indicators for the Knowledge-based Society. Measuring the Sustainability of the Information Society. In: Futura, Vol. 21, No. 2, pp. 85-95. - URL: https://www.doria.fi/handle/10024/22994

Stehr, Nico, Knowledge Societies, London (Sage) 1994

Stern, N. H. (2007): The Economics of Climate Change. Cambridge

Stirling, A. (2006): Precaution, Foresight and Sustainability. Reflection and Reflexivity in the Governance of Science and Technology. In: Voß, J.-P.; Bauknecht, D.; Kemp, R. (eds.): Reflexive Governance for Sustainable Development. Cheltenham, pp. 225-272

Suh, S. (2005): Theory of Materials and Energy Flow Analysis in Ecology and Economics. In: Ecological Modelling, Vol. 189, Issue 3-4 (December 10), pp. 251-269. - URL: http://dx.doi.org/10.1016/j.ecolmodel.2005.03.011

Thompson-Klein, J.; Grossenbacher-Mansuy, W.; Häberli, R.; Bill, A.; Scholz, R. W.; Welti, M. (eds.) (2001): Transdisciplinarity: Joint Problem Solving among Science, Technology, and Society. An Effective Way for Managing Complexity. Basel/Boston/Berlin

Toffler, A. (1980): The Third Wave. New York

Türke, R.-E. (2008): Governance. Systemic Foundation and Framework. Heidelberg

UN - United Nations (2007): Indicators of Sustainable Development. Guidelines and Methodologies. $3^{\text {rd }}$ ed. New York

Voss, J.-P.; Bauknecht, D.; Kemp, R. (eds.) (2006): Reflexive Governance for Sustainable Development. Cheltenham

Wajcman, J.; MacKenzie, D. A. (eds.) (1985): The Social Shaping of Technology. How the Refrigerator Got its Hum. Milton Keynes

Walz, R.; Kuhlmann, St. (2005): Nachhaltigkeitsinnovationen in systemischer Perspektive. In: Mappus, St. (ed.): Erde 2.0. Technologische Innovationen als Chance für eine nachhaltige Entwicklung. Heidelberg a.o., pp. 278-310 (in German)

Watts, M. J.; Bohle, H. G. (1993): The Space of Vulnerability. The Causal Structure of Hunger and Famine. In: Progress in Human Geography, Vol. 17, No. 1, pp. 43-67 
WBGU - German Advisory Council on Global Change (2000): World in Transition. Strategies for Managing Global Environmental Risks. Annual Report 1998. Berlin a.o.

WCED - World Commission on Environment and Development (ed.) (1987): Our Common Future (Brundtland-Report). Oxford/New York

Wehling, P. (2006): Im Schatten des Wissens? Perspektiven der Soziologie des Nichtwissens. Konstanz (in German)

Willinger, W.; Doyle, J. (2002): Robustness and the Internet - Design and Evolution. Pasadena. URL: http://netlab.caltech.edu/pub/papers/part1_vers4.pdf

Willke, Th.; Vorlop, K.-D. (2004): Industrial Bioconversion of Renewable Resources as an Alternative to Conventional Chemistry. In: Applied Microbiology and Biotechnology, Vol. 66, No. 2, pp. 131-142. - URL: http://dx.doi.org/10.1007/s00253-004-1733-0

WEF - World Economic Forum (2010): Global Risks 2010. A Global Risk Network Report. Geneva

Young, O. R.; Berkhout, F.; Gallopin, G. C.; Janssen, M. A.; Ostrom, E.; Leeuw, S. van der (2006): The Globalization of Socio-ecological Systems. An Agenda for Scientific Research. In: Global Environmental Change, Vol. 16, No. 3 (August), pp. 304-316. - URL: http://dx.doi.org/10.1016/j.gloenvcha.2006.03.004 